\title{
AKIBAT HUKUM PENCABUTAN BERITA ACARA PEMERIKSAAN SAKSI DI DEPAN PERSIDANGAN DALAM TINDAK PIDANA NARKOTIKA
}

(Studi Putusan Nomor 201/Pid.Sus/2018/PN Simalungun)

\author{
Pondang Hasibuan', Sahat Benny Risman Girsang ${ }^{2}$, Erni Juniria Harefa ${ }^{3}$, \\ Janpatar Simamora ${ }^{4}$, Herlina Manullang ${ }^{5}$ \\ Program Studi Magister Hukum \\ Program Pascasarjana \\ Universitas HKBP Nommensen, Medan-Sumatera Utara-Indonesia \\ e-mail: pondanghasibuan@gmail.com
}

\begin{abstract}
During the trial, witnesses were often found retracting the testimony of witnesses given during the investigation (Police) in court. There are many reasons that the revocation is given by the witness to revoke the witness's BAP that has been given before the investigator. The problem studied is how the consequences of the revocation of the BAP in front of the trial affect the judge's decision in Decision No. 201/Pid.Sus/2018/PN Simalungun. The research method uses a normative juridical approach, which is an approach based on the main legal material by examining theories, concepts, legal principles and legislation. In Decision No. 201/Pid.Sus/2018/PN Sim that the strength of the evidence of the witness's BAP becomes an integral part of the investigation file and is finally transferred to the District Court for trial, it has become evidence of affidavits. That the consequence of the revocation of the witness's BAP before the trial in Decision No. 201/Pid.Sus/2018/PN.Sim did not affect the judge's decision to convict the defendant, because the Panel of Judges considered that the revocation of the witness's BAP did not have a strong reason and the defendant's actions were also categorized as extraordinary crime.

Keywords : Legal Consequences, BAP, Witnesseses and Narcotics Crime
\end{abstract}

\begin{abstract}
Abstrak
Dalam persidangan sering dijumpai para saksi mencabut keterangan saksi yang diberikan dalam pemeriksaan penyidikan (Polisi) di sidang pengadilan. Ada banyak alasan yang pencabutan diberikan oleh saksi untuk mencabut BAP saksi yang telah diberikan dihadapan penyidik. Permasalahan yang diteliti adalah Bagaimanakah konsekeuensi pencabutan BAP di depan persidangan mempengaruhi keputusan hakim dalam Putusan No 201/ Pid.Sus /2018/PN Simalungun. Metode Penelitian menggunakan pendekatan yuridis normatif, yaitu pendekatan yang dilakukan berdasarkan bahan hukum utama dengan cara menelaah teori-teori, konsepkonsep, asas-asas hukum serta peraturan perundang-undangan. Dalam Putusan No 201/Pid.Sus/2018/PN Sim bahwa kekuatan pembuktian BAP saksi menjadi satu kesatuan dengan berkas penyidikan dan akhirnya kemudian dilimpahkan ke Pengadilan Negeri untuk dilakukan persidangan, telah menjadi alat bukti keterangan surat. Bahwa konsekuensi pencabutan BAP saksi di depan persidangan dalam Putusan No 201/Pid.Sus/2018/PN.Sim ternyata tidak mempengaruhi keputusan Hakim untuk menghukum terdakwa, sebab Majelis Hakim memiliki pertimbangan pencabutan BAP saksi tidak memiliki alasan yang kuat dan perbuatan terdakwa juga dikategorikan kejahatan luar biasa.

Kata Kunci : Akibat Hukum, Pencabutan BAPk dan Tindak Pidana Narkotika
\end{abstract}


Jurnal Magister Hukum Program Pascasarjana Universitas HKBP Nommensen

Volume or Nomor o1 Juli 2020 Halaman. 129-138 e-ISSN: 2723-164X p-ISSN: 2722-9858

http://ejournal.uhn.ac.id/index.php/opinion

\section{A. Pendahuluan}

Hukum Acara Pidana atau hukum pidana formal mengatur cara bagaimana pemerintah menjaga kelangsungan pelaksanaan hukum pidana materil. Penyelenggaraan di lakukan berdasarkan Undang-Undang Nomor 8 Tahun 1981 Kitab Undang-undang Hukum Acara Pidana (KUHAP). Sedangkan tujuan yang akan dicapai hukum acara pidana adalah untuk mencari atau setidak-tidaknya mendekati kebenaran materiil, yakni kebenaran yang selengkap-lengkapnya dari suatu perkara pidana dengan menerapkan ketentuan hukum acara pidana secara jujur dan tepat, hal ini bertujuan untuk mencari siapakah pelaku yang dapat dijadikan terdakwa dalam suatu kasus, kemudian dilakukan pemeriksaan dan putusan pengadilan guna menemukan terbukti bersalah atau tidaknya terdakwa dalam suatu pelanggaran hukum dilanjutkannya dengan pelaksanaan atas putusan tersebut oleh terpidana. Mencari kebenaran materiil dalam perkara pidana diperlukan proses-proses mulai dari penyelidikan oleh pejabat kepolisian, penyidikan yang dilakukan oleh penyidik atau Penuntut Umum dan pemeriksaan serta Putusan Hakim.

Pembuktian adalah upaya untuk meyakinkan hakim tentang kebenaran dalil -dalil yang dikemukakan dalam suatu persengketaan. Dengan demikian pembuktian diperlukan dalam persengketaan atau perkara di muka hakim atau pengadilan. ${ }^{.}$Oleh karena itu seseorang tidak dapat dihukum, kecuali jika hakim berdasarkan alat alat bukti yang sah memperoleh keyakinan, bahwa suatu tindak pidana telah terjadi dan bahwa terdakwa telah bersalah melakukannya. ${ }^{2}$ Pembuktian memegang peranan yang sangat penting dalam proses pemeriksaan sidang pengadilan, karena dengan pembuktian inilah nasib terdakwa ditentukan, dan hanya dengan pembuktian suatu perbuatan pidana dapat dijatuhi hukuman pidana. Keberadaan hukum pidana dengan sanksi pidana masih dikedepankan. ${ }^{3}$ Sehingga apabila hasil pembuktian dengan alat alat bukti yang ditentukan tidak cukup membuktikan kesalahan yang didakwakan kepada terdakwa, maka terdakwa dapat dibebaskan dari hukuman, dan sebaliknya jika kesalahan dapat dibuktikan, maka terdakwa harus dinyatakan bersalah dan kepadanya akan dijatuhjan pidana.

Pasal 184 KUHAP menyebutkan alat bukti yang sah dalam pembuktian di persidangan perkara pidana adalah terdiri, pertama keterangan saksi, kedua keterangan ahli, ketiga, surat, keempat, petunjuk, kelima, keterangan terdakwa. Keterangan saksi KUHAP menjadi alat bukti sangat penting dan utama dalam membuktikan kesalahan terdakwa, maka dari itu hakim dituntut untuk cermat dan teliti. Ketika Hakim mengambil keputusan juga terikat terhadap ketentuan Pasal 183 KUHAP yang menyebutkan "bahwa untuk menentukan pidana kepada terdakwa, kesalahannya harus terbuktikan dengan sekurang-kurangnya dua alat bukti yang sah tersebut, hakim memperoleh keyakinan bahwa tindak pidana benar benar terjadi dan bahwa terdakwalah yang bersalah melakukannya".

Dalam pelaksanaan tugas dan wewenang penegakan hukum pidana dilaksanakan oleh aparatur negara seperti Kepolisian, Kejaksaan serta Pengadilan. Selanjutnya para penegak hukum ini akan mencari kebenaran dalam perkara pidana dengan melewati proses-proses antara lain, penyidikan yang dilakukan oleh Penyidik, Pununtutan oleh Jaksa Penuntut $\mathrm{Umum}^{4}$ dan pemeriksaan sidang pengadilan disertai dengan putusan oleh Hakim.

\footnotetext{
${ }^{1}$ R Subekti,2008, Hukum Pembukitan, Cetakan Ke 17, Jakarta, Pradnya Paramita, hal 1

${ }^{2}$ Ibid

${ }^{3}$ Reza Fahlepy, 2018, Analisis Hukum Islam Terhadap Jarimah Minta-Minta Yang Dilakukan oleh Anak, Jurnal de Jure 10, No 2, hal 20

${ }^{4}$ Janpatar Simamora, Kepastian Hukum Pengajuan Kasasi oleh Jaksa Penuntut Umum Terhadap Vonis Bebas, Jurnal Yudisial, Komisi Yudisial RI, Vol. 7 No. 1 April 2014, hlm. 1-17.
} 
Dalam kedudukannya penyidik harus membuat Berita Acara Pemeriksaan (BAP) atas segala tindakannya dalam proses penyidikan, terkaitan antara BAP dengan Hukum Pembuktian sangatlah erat, disebabkan BAP di jadikan dasar oleh Jaksa Penuntut Umum (JPU) dalam pembuatan Surat Dakwaan, dan dasar membuktikan kesalahan terdakwa dalam proses pemeriksaan di persidangan, karena itu kebenaran BAP selalu dipertahankan oleh Jaksa Penuntut Umum (JPU). BAP yang memenuhi syarat pembuktian adalah BAP yang dapat memberikan jawaban atas pertanyaan: apa, kapan, dimana, siapa, mengapa, dan bagaimana, terhadap peristiwa pidana yang disangkakan. Martiman Prodjohamidjojo, memberikan pengertian BAP adalah keterangan di muka penyidik dan keterangan dalam persidangan harus dibedakan, keterangan yang diberikan di muka penyidik disebut keterangan tersangka, sedangkan keterangan yang diberikan dalam persidangan disebut keterangan terdakwa. ${ }^{5}$ Dengan adanya perbedaan ini tentunya akan mempermudah dan memperjelas kedudukan masing masing keterangan terutama dalam pembuktian.

Dalam persidangan sering di jumpai para saksi mencabut keterangan yang diberikan dalam pemeriksaan penyidikan di sidang pengadilan. Suatu hal yang ironi tersangka pasti memberikan keterangan pengakuan di depan penyidik sedemikian rupa jelasnya mengutarakan dan menggambarkan jalannya perbuatan tindak pidana yang disangkakan, Akan tetapi demikian gamblangnya pengakuan yang tercatat dalam BAP, para saksi sering sekali mencabut kembali keterangan yang dibuat dihadapan penyidik dalam pemeriksaan pengadilan. Proses persidangan perkara pidana harus dilakukan demi keadilan (Pro Justitia) sehingga kesungguhan majelis hakim mutlak diperlukan oleh karena itu peristiwa pencabutan kesaksian saksi saki dalam perkara pidana harus dicermati secara serius oleh Majelis Hakim serta secara serius menyikapinya dan mempertanyakan apa latar belakang atau sebab para saksi melakukan hal tersebut.

Adapun alasan yang kerap dijadikan dasar pencabutan BAP adalah bahwa pada saat memberikan keterangan di hadapan penyidik, para saksi dipaksa atau diancam dengan kekerasan baik fisik maupun psikis untuk mengakui terjadinya tindak pidana.Sedemikian rupa penyiksaan dan ancaman berupa pemukulan, penyulutan bagian badan atau bagian vital tubuh. Kepala dibenturkan di dinding, dan segala macam penganiayaan yang keji, membuat para saksi terpaksa mengakui segala pertanyaan yang didiktekan pejabat pemeriksa. Begitulah selalu alasan yang melandasi setiap pencabutan keterangan pengakuan yang dijumpai di sidang pengadilan.

Secara yuridis, pencabutan BAP dibolehkanakan tetapi dengan persyaratan, bahwa pencabutan dilakukan selama proses persidangan pengadilan berlangsung dan disertai dengan alasan-alasan logis. Sepintas terkesan bahwa syarat pencabutan tersebut mudah dipahami dan mudah untuk dilakukan sehingga diperkirakan penerapannya pun akan lancar tanpa permasalahan. Akan tetapi, pada kenyataannya tidaklah demikian karena ternyata dalam praktek di persidangan pencabutan demikian banyak menimbulkan permasalahan.

Apabila peristiwa pencabutan keterangan kesaksian terjadi terus menerus dalam perkara pidana menyebabkan seolah-olah pemeriksaan perkara pidana tidak dilakukan secara serius tetapi dianggap main-main saja. Disinilah diperlukan inisiatif dan kreativitas hakim untuk menyikapi latar belakang dan sebab pencabutan kesaksian para saksi. Jika pencabutan kesaksian tidak jelas, maka hakim bebas untuk menggunakan kesaksian para saksi sebagai bahan pertimbangan dan fakta hukum untuk membuat keputusan yang tepat dan adil, setelah kesaksiaan saksi-saksi a charge (saksi yang memberatkan) dihadapkan dengan kesaksian

\footnotetext{
${ }^{5}$ Martiman Prodjohamidjojo,1984, Komentar Atas KUHAP: Kitab Undang-Undang Hukum Acara Pidana, Jakarta, Pradnya Paramita, hal 137.
} 
saksi-saksi $a$ de charge (saksi yang meringankan) karena tujuan dari putusan pengadilan adalah mencari kebenaran materiil dan keadilan.

Masalah pencabutan keterangan saksi-saksi dalam Perkara Tindak Pidana Narkotika, Bahwa setiap orang yang tanpa hak menawarkan untuk dijual, menjual, membeli, menerima, menjadi perantara dalam jual beli, menukar, atau menyerahkan Narkotika Golongan I tersebut adalah tanpa hak memiliki ijin yang sah dari pihak yang berwenang, sebagaimana dimaksud dalam Pasal 114 ayat (1) UU RI No.35 Tahun 2009 tentang Narkotika atau Pasal 111 ayat (1) UU RI No,35 Tahun 2009 tentang Narkotika atau Pasal 127 ayat (1) huruf a UU No.35 Tahun 2009 tentang Narkkotika. Ini yang membawa permasalahan lain yaitu persoalan terhadap Akibat Hukum Pencabutan Berita Acara Pemeriksaan Saksi di Depan Persidangan. Berdasarkan latar belakang yang telah diuraikan oleh peneliti, maka permasalahan yang menjadi perhatian peneliti adalah, Bagaimanakah pencabutan BAP saksi di depan persidangan mempengaruhi keputusan Hakim Dalam Tindak Pidana Narkotika Studi Putusan No 201/ Pid.Sus /2018/PN Simalungun?

\section{B. Metode Penelitian}

Jenis penelitian yang digunakan adalah penelitian yuridis normatif, yaitu pendekatan yang memfokuskan untuk menelaah dan menganalisis norma-norma hukum, asas-asas hukum yang terdapat di dalam undang-undang, maupun di dalam hukum acara pidana beserta peraturan-peraturan lainnya yang berkaitan dengan objek penelitian. ${ }^{6}$ Penelitian hukum normatif menurut Ronal Dworkin disebut dengan istilah penelitian doktrinal (doctrinal research), yaitu penelitian yang menganalisis hukum baik yang tertulis didalam buku (law as it written in the book), maupun hukum yang diputuskan oleh hakim melalui proses pengadilan (law as it it decided by the judge through judicial process). ${ }^{7}$

Untuk mendukung penelitian dipergunakan pendekatan perundang-undangan (Statute Approach) dengan mengkaji peraturan perundang-undangan dan regulasi yang bersangkut paut dengan isu hukum yang sedang diteliti. Bagi peneliti untuk kegiatan praktis, pendekatan undang-undang ini akan membuka kesempatan bagi peneliti untuk mempelajari konsistensi dan kesesuaian antara satu jenis peraturan perundang-undangan dengan jenis lainnya atau antara regulasi dan undang-undang. Hasil telaah tersebut merupakan suatu argument untuk menghadapi isu yang dihadapi. ${ }^{8}$ Dan pendekatan kasus (Case Approach) yang bertujuan untuk mengetahui penerapan norma atau kaidah hukum dalam praktik hukum, untuk mengetahui kaidah hukum atau norma hukum yang diterapkan dalam kasus-kasus yang telah diputus baik oleh hakim maupun lembaga lain yang berwenang memutuskan suatu perkara. Sumber bahan hukum yang dipergunakan adalah bahan hukum sekunder yang terdiri dari data primer, data sekunder dan data tersier.

\section{Pembahasan}

\section{Pengertian Berita Acara Pemeriksaan}

Berita acara pemeriksaan adalah catatan yang berisi mengenai segala kejadian dalam penyidikan yang berhubungan dengan pemeriksaan di tingkat penyidikan berupa pemeriksaan

\footnotetext{
${ }^{6}$ Soerjono, Soekanto dan Sri Mamudji, 1995, Penelitian Hukum Normatif, Suatu Tinjauan Singkat, Raja Grafindo Persada, Jakarta, hlm. 12

${ }^{7}$ Bismar Nasution, Metode Penelitian Hukum Normatif dan Perbandingan Hukum, Makalah disampaikan pada dialog interaktif tentang Penelitian Hukum dan Hasil Penulisan Hukum pada Majalah Akreditasi, Fakultas Hukum USU, 18 Februari 2003, hlm. 1

${ }^{8}$ Peter Mahmud Marzuki, 2006, Teori dan Metodologi Penelitian Hukum Normatif, Jakarta, Prenada Media, hal 192.
}

Akibat Hukum Pencabutan Berita Acara Pemeriksaan Saksi di Depan Persidangan dalam Tindak Pidana Narkotika (Studi Putusan Nomor201/Pid.Sus/2018/PN Simalungun) 
Jurnal Magister Hukum Program Pascasarjana Universitas HKBP Nommensen

Volume o1 Nomor o1 Juli 2020 Halaman. 129-138 e-ISSN: 2723-164X p-ISSN: 2722-9858

http://ejournal.uhn.ac.id/index.php/opinion

terhadap tersangka, pemeriksaan terhadap saksi, pemeriksaan terhadap saksi ahli dan penghentian penyidikan. ${ }^{9}$

Berita acara pemeriksaan ini di jadikan jaksa penuntut umum sebagai dasar untuk membuat dakwaan. oleh karena itu jaksa penuntut umum harus ikut aktif dalam menentukan arah penyidikan. Pada waktu HIR masih berlaku sebagai hukum acara pidana di Indonesia, penyidikan dianggap bagian dari penuntutan. Kewenangan yang demikian menjadikan Penuntut Umum sebagai koordinator penyidikan, bahkan jaksa dapat melakukan sendiri penyidikan.

Namun setelah KUHAP di berlakukan pada Tahun 1981 melalui Undang Undang Nomor 8 Tahun 1981wewenang penyidikan dibebankan kepada POLRI sebagai penyidik tunggal walaupun masih ada penyidik lain,yaitu Penyidik Pegawai Negeri Sipil (PPNS) yang kewenangannya sangat terbatas dan di bawah koordinasi penyidik POLRI. Walaupun demikian masih ada penyidik lain yaitu Jaksa, yang melakukan penyidikan bagi pelaku tindak pidana tertentu. ${ }^{10}$

BAP sangat menentukan dalam proses pembuktian di dalam persidangan karena BAP inilah yang menjadi dasar dalam pemeriksaan di persidangan baik oleh Hakim, Jaksa maupun Penasehat Hukum. Meskipun BAP ini bukan merupakan alat bukti yang sah namun BAP dapat dijadikan hakim sebagai petunjuk dalam pembuktian. Akan tetapi, dalam praktek sering terjadi keterangan saksi dan keterangan terdakwa yang tercantum di dalam BAP tidak sama dengan keterangan yang diberikan pada saat persidangan atau dengan kata lain saksi dan terdakwa mencabut keterangannya di BAP pada saat persidangan. Oleh karena itu hakim harus jeli dalam menyikapi pencabutan berita acara pemeriksaan yang di lakukan oleh saksi dan terdakwa di persidangan."

Apabila terjadi pencabutan BAP maka Hakim harus mempertanyakan alasan pencabut keterangan yang telah diberikan dalam BAP. Apabila alasan yang di berikan oleh saksi atau terdakwa karena tidak sesuai dengan dengan tata cara pemeriksaan penyidikan yang telah ditentukan oleh undang-undang maka hakim harus memanggil penyidik untuk dimintai keterangan.

\section{Alat Bukti yang Sah Menurut KUHAP}

Alat bukti dapat diberi pengertian segala sesuatu yang ada hubungannya dengan suatu perbuatan, dimana alat alat bukti tersebut, dapat dipergunakan sebagai bahan pembuktian guna menimbulkan keyakinan Hakim atas kebenaran adanya suatu tindak pidana yang dilakukan oleh terdakwa. Adapun alat-alat bukti yang sah menurut Pasal 184 ayat (1) KUHAP, adalah sebagai berikut : Pertama Keterangan saksi. Menurut Pasal 1 Angka 27 KUHAP, keterangan saksi adalah salah satu alat bukti dalam perkara Pidana yang berupa keterangan dari saksi mengenai suatu peristiwa Pidana yang ia dengar sendiri, ia lihat sendiri, dan ia alami sendiri dengan menyebut alasan dari pengetahuan.

Kedua, Keterangan Ahli Menurut Pasal 1 Angka 28 KUHAP, keterangan ahli adalah keterangan yang diberikan oleh seorang yang memiliki keahlian khusus tentang hal yang diperlukan untuk membuat terang suatu perkara Pidana guna kepentingan pemeriksaan dalam hal serta menurut cara yang diatur dalam undang-undang.

\footnotetext{
${ }^{9}$ Bambang Semedi, 2009," Modul Pemeriksaan Tersangka Dan Saksi”, Departemen Keuangan Republik Indonesia Badan Pendidikan Dan Pelatihan Keuangan Pusat Pendidikan Dan Pelatihan Bea Dan Cukai, hal 65

${ }^{10}$ Marwan Effendi. 2005, Kejaksaan RI: Posisi Dan Fungsinya Dari Perspektif Hukum. Jakarta. Gramedia Pustaka Utama. hal. 145

${ }^{11}$ Ibid
}

Akibat Hukum Pencabutan Berita Acara Pemeriksaan Saksi di Depan Persidangan dalam Tindak Pidana Narkotika (Studi Putusan Nomor201/Pid.Sus/2018/PN Simalungun) 
Ketiga, Surat menurut Pasal 187 KUHAP, Surat sebagaimana tersebut pada Pasal 184 ayat (1) huruf c, dibuat atas sumpah jabatan atau dikuatkan dengan sumpah, adalah : a. Berita acara dan surat lain dalam bentuk resmi yang dibuat oleh pejabat umum yang berwenang atau yang dibuat dihadapannya, yang memuat keterangan tentang kejadian atau keadaan yang didengar, dilihat atau yang dialaminya sendiri, disertai dengan alasan yang jelas dan tegas tentang keterangannya itu.;b. Surat yang dibuat menurut ketentuan peraturan perundang-undangan atau surat yang dibuat oleh pejabat mengenal hal yang termasuk dalam tata laksana yang menjadi tanggung jawabnya dan yang diperuntukkan bagi pembuktian sesuatu hal atau sesuatu keadaan; c. Surat keterangan dari seorang ahli yang memuat pendapat berdasarkan keahliannya, mengenai sesuatu hal atau sesuatu keadaan yang diminta secara resmi dan padanya; d.Surat lain yang hanya dapat berlaku jika ada hubungannya denga nisi dari alat pembuktian lain.

Keempat. Petunjuk Menurut Pasal 188 KUHAP ayat (1), Petunjuk adalah perbuatan, kejadian atau keadaan, yang karena persesuaiannya, baik antara yang satu dengan yang lain, maupun dengan tindak Pidana itu sendiri, menandakan bahwa telah terjadi suatu tindak pidana dan siapa pelakunya. Kelima, Keterangan terdakwa, berdasarkan Pasal 189 ayat (1) KUHAP, keterangan terdakwa adalah apa yang terdakwa nyatakan di sidang tentang perbuatan yang dilakukan atau ia ketahui sendiri atau alami sendiri. Dasar hukum alat bukti keterangan terdakwa, a. Keterangan terdakwa Pasal 184 huruf c dan Pasal 189 KUHAP, b. Pemeriksaan terdakwa Pasal 175 sampai Pasal 178 KUHAP.

\section{Alasan Hukum Terjadinya Pencabutan BAP Penyidik Dalam Pemeriksaan Saksi di Depan Persidangan}

Pasal 187 huruf a KUHAP mengatur bahwa BAP termasuk BAP saksi merupakan kedudukannya adalah sebagai alat bukti surat. Mengenai BAP saksi sebagai alat bukti surat telah dikuatkan dengan adanya Surat Edaran Mahkamah Agung No.1 Tahun 1985 tentang Kekuatan Pembuktian Berita Acara Pemeriksaan Saksi dan Visum et Repertum yang dibuat di Luar Negeri oleh Pejabat Asing. Ketentuan Surat Edaran Mahkamah Agung ini memberi penegasab bahwa BAP, termasuk BAP Saksi, bukan hanya sebagai pedoman hakin untuk memeriksa suatu perkara pidana, melainkan sebuah alat bukti yang memiliki kekuatan pembuktian. Dalam hal merujuk Pasal 187 huruf a KUHAP BAP merupakan alat bukti surat, termasuk juga BAP pemeriksaan saksi yang dibuat di luar negeri oleh pejabat asing.

Pendapat para ahli hukum juga sependapat bahwa BAP Saksi sebagai alat bukti surat, bahkan R Soesilo berpendapat BAP saksi merupakan alat bukti keterangan saksi dengan pendapat sebagai berikut: "Sesungguhnya berita acara itu dapat disamakan dengan suatu keterangan saksi yang tertulis, bahkan nilainya sebagai alat bukti lebih besar dari kesaksian untuk membuktikan kesalahan terdakwa, oleh karena berita acara itu dibuat oleh pegawai penyidik yang oleh undang-undang diwajibkan untuk itu. Pada hakekatnya berita acara adalah suatu keterangan saksi yang oleh undang-undang diberi nilai sebagai bukti sah.”

Hal ini juga sejalan dengan pendapat Teguh Samudera ${ }^{13}$ BAP adalah gologan akta autentiek yang dibuat oleh pegawai umum, yakni pejabat penyidik yang bersangkutan yang merupakan laporan tentang sesuatu perbuatan atau kejadian resmi yang telah dilakukan olehnya. Fenomena yang sering terjadi di dalam praktik peradilan di Indonesia dewasa ini adalah seorang saksi atau terdakwa ketika memberikan keterangan di depan persidangan dapat menarik atau mencabut keterangan yang telah diberikan di dalam BAP Saksi yang dibuat oleh penyidik. Belum ada pengaturan di dalam KUHAP mengenai hal keterangan BAP Saksi

\footnotetext{
${ }^{12}$ Kekuatan Pembuktian BAP Saksi di Persidangan, Hukumonline.com, diunduh tgl 10 Juli 2021

${ }^{13}$ Teguh Samudera, 2004, Hukum Acara Perdata, Bandung, Alumni, hal 45
} 
yang ditarik/dicabut di muka persidangan. Jika seorang saksi "menarik/mencabut" keterangannya di dalam BAP Saksi dan terdakwa yang dibuat dihadapan penyidik maka berlakulah ketentuan Pasal 185 ayat (1) KUHAP yang menyebutkan :"keterangan saksi sebagai alat bukti adalah apa yang saksi nyatakan dimuka sidang pengadilan" dengan bunyi pasal 185 ayat (1) KUHAP bermakna keterangan saksi yang diberikan dalam pemeriksaan di muka sidang pengadilan yang berlaku sebagai alat bukti yang sah yaitu sebagai alat bukti petunjuk (pasal 188 ayat (2)KUHAP).

Saksi atau Terdakwa mencabut kembali BAP Saksi di depan penyidik dilakukan dengan berbagai alasan yang baku; antara lain pengakuan yang diberikan karena tidak sanggup menahan siksaan dan penganiayaan yang ditimpakan penyidik wakti pemeriksaan penyidikan. Sedemikian rupa penyiksaan dan ancaman berupa pemukulan, penyulutan bagian badan atau bagian vitas tubuh. Kepala dibenturkan ke dinding, dan segala macam penganiayaan yang keji, membuat mereka terpaksa mengakui segala pertanyaan yang didekiktekan pejabat pemeriksaan Demikianlah sejumlah alasan yang melandasi setiap pencabutan keterangan yang kerap dijumpai di sidang pengadilan. Tentu tidak selamanya keterangan tersebut dapat dipercaya sebagai alasan.

Untuk mengetahui penyebab terjadinya pencabutan BAP Saksi dan Terdakwa yang dibuat dihadapan penyidik dalam kasus narkoba, maka dalam BAP Acara pemeriksaan Saksi dalam Putusan Pengadilan Negeri Simalungun 201/Pid.Sus/2018/PN Sim yaitu adanya saksi $a$ de charge yaitu merupakan saksi yang diajukan terdakwa dalam rangka melakukan pembelaan diri atas dakwaan yang diberikan kepada Terdakwa adalah disebabkan alasan adanya intimidasi atau ancaman dari Penyidik.

Berdasarkan Pasal 163 KUHAP, saksi boleh memberikan keterangan yang berbeda dengan apa yang terdapat pada BAP saksi. Dalam keadaan ini saksi haruslah memberikan alasan yang dapat diterima oleh akal sehat mengenai keterangan yang berbeda tersebut.Jika terjadi perbedaan keterangan sebagaimana yang disebutkan diatas, maka keterangan didepan persidanganlah yang lebih diutamakan. Bila yang diutamakan keterangan dalam BAP saksi maka otomatis dakwaan penuntut umum terbukti seluruhnya. Bila hal ini terjadi, maka hakim dapat melakukan pemanggilan terhadap penyidik yang membuat BAP.

Dalam keadaan ini peran hakim sebagai hakim yang aktif dalam mencari kebenaran materiil, yang merupakan ciri khas hakim dalam sistem peradilan negara yang menganut sistem civil law, ${ }^{14}$ ketika terjadi perbedaan keterangan yang diberikan saksi, maka hakim harus melihar apakah keterangan atau alasan yang diberikan saksi secara logika dan masuk akal dapat mendukung terjadinya perbedaan keterangan tersebut.

\section{Konsekuensi Pencabutan BAP Saksi di Depan Persidangan Dalam Putusan No 201/ Pid.Sus /2018/PN Simalungun}

Dalam Hukum Acara Pidana, seorang hakim mencari kebenaran yang hakiki (bersifat materiil), sedangkan dalam hukum acara perdata kebenaran formil saja sudah cukup. ${ }^{15}$ Berdasarkan hal tersebut, pembuktian merupakan hal yang mutlak ada dalam pemeriksaan pidana. Karena menyangkut mengenai benar tidaknya terdakwa melakukan perbuatan yang di dakwakan kepadanya. Keseluruhan rangkaian tindakan penyelidikan maupun penyidikan

${ }^{14}$ Janpatar Simamora, Tafsir Makna Negara Hukum dalam Perspektif Undang-Undang Dasar Negara Republik Indonesia Tahun 1945, Jurnal Dinamika Hukum FH Universitas Jenderal Soedirman, Vol. 14 No. 3 September 2014, hlm. 547-561.

${ }^{15}$ R.Subekti, Op.cit, hal.9 
Jurnal Magister Hukum Program Pascasarjana Universitas HKBP Nommensen

Volume or Nomor o1 Juli 2020 Halaman. 129-138 e-ISSN: 2723-164X p-ISSN: 2722-9858

http://ejournal.uhn.ac.id/index.php/opinion

tersebut diatas disebut sebagai pemeriksaan pendahuluan (vooronderzoek) yaitu pemeriksaan sebelum ke muka persidangan pengadilan. ${ }^{16}$

Dalam pemeriksaan pendahuluan ini yang perlu diketengahkan adalah mengenai tersangka dan terdakwa, dan bantuan hukum sepanjang dalam tahap pemeriksaan pendahuluan. Hal yang sangat penting kemudian dalam pelaksanaan tindakan penyidikan, yang berpengaruh bagi tingkat pemeriksaan lebih lanjut maupun dalam pemeriksaan di muka persidangan (gerectelijk onderzoek) adalah pembuatan berita acara pemeriksaan (selanjutnya disingkat BAP). BAP disini akan memuat suatu cerita tentang duduknya perkara juga mengenai suatu ulangan pemberitaan yang disampaikan oleh saksi, pengadu, pelapor, maupun tersangka sendiri.

Proses persidangan perkara pidana adalah dilakukan demi keadilan (Pro Justitia) sehingga kesungguhan majelis hakim mutlak diperlukan oleh karena itu peristiwa pencabutan kesaksian saksi-saksi dalam perkara pidana seharusnya harus menjadi perhatian Majelis Hakim dan Hakim harus secara yuridis menyikapinya dan mempertanyakan latar belakang atau sebab para saksi melakukan hal tersebut.

Pencabutan berita pemeriksaan saksi (BAP) saksi, telah terjadi pada saat persidangan kasus tindak pidana Narkotika dalam Putusan No 201/Pid.Sus/2018/PN Simalungun adalah :

1. Majelis Hakim memberi pertimbangan menyatakan bahwa surat dakwaan Jaksa Penuntut Umum No.REG.PDM-84/Simal/N.2.24/EUH/o3/2018 yang disusun dalam bentuk alternatif tetap dapat diterima dengan memperhatikan fakta -fakta hukum dan Majelis Hakim langsung mempertimbangkan bahwa dakwaan ketiga yang lebih bersesuaian dengan fakta persidangan yaitu Pasal 127 ayat (1) huruf a UU RI No.35 Tahun 2009 yang unsur-unsurnya sebagai berikut :

a. Setiap orang

b. Menyalahgunakan Narkotika Golongan I bagi diri sendiri.

2. Berkaitan dengan alasan alasan pencabutan keterangan saksi-saksi dalam persidangan Putusan No 201/ Pid.Sus /2018/PN Simalungun al : Saksi Irianto Dedi Firmansyah, Ferdi Herdi Aldian Firmansyah, Azhari Lubis, Mulyono alias Babe yang telah dituangkan oleh saksi-saksi dalam masing-masing pernyataan atas nama saksi-saksi yang pada pokoknya mengandung makna yang sama mencabut keterangan saksi yang pernah diberikan dan minta dilakukan pemeriksaan ulang karena pemeriksaan yang terdahulu dilakukan dalam keadaan tidak tenang dan pikiran kacau serta mendapat tekanan daan ancaman dari Hairul Amri Pandi, dkk dan selanjutnya saksi-saksi menyatakan bahwa hal tersebut bukan milik Samuel Patrick Sinaga dan Toni Toiman alias Ahwat. Bahwa Majelis Hakim telah memberikan pertimbangan : bahwa dalam teori dan praktek hukum pidana dijelaskan tentang proses persidangan perkara pidana adalah dilakukan demi keadilan (Pro Justitia) sehingga kesungguhan Hakim mutlak diperlukan dan dalam peristiwa pencabutan kesaksian saksi-saksi dalam perkara harus secara serius menyikapinya dan mengetahui latar belakang/penyebab saksi-saksi melakukan hal tersebut, sehingga dalam hal menerima pencabutan keterangan saksi telah diberikan di BAP Penyidik harus mempunyai landasan /alasan yang kuat yang dapat diterima secara akal sehat dan juga logika hukum, dan sebaliknya jika pencabutan kesaksian yang diterima begitu saja dapat mengesankan bahwa pemeriksaan perkara tersebut tidak dilakukan secara serius dalam mencari kebenarar materiil.

3. Majelis Hakim telah merujuk Pasal 185 ayat (6) KUHAP, yaitu menilai keterangan seorang saksi, maka harus dengan sungguh-sungguh memperhatikan :

a. Persesuaian antara keterangan saksi satu dengan yang lain:

\footnotetext{
${ }^{16}$ Soedjono D, 1982, Pemeriksaan Pendahuluan, menurut KUHAP, Alumni, Bandung, hal. 10
} 
b. Perseuaian antara keterangan saksi dan alat bukti lain;

c. Alasan yang mungkin dipergunakan oleh saksi untuk memberi keterangan tertentu;

d. Cara hidup dan kesusilaan saksi serta segala sesuatu yang pada umumnya dapat mempengaruhi dapat tidaknya keterangan itu dipercaya.

Berkaitan dengan surat pernyataan pencabutan BAP saksi yang sebelumnya telah diberikan dihadapan penyidik, Majelis Hakim berpendapat bahwa hal tersebut suatu hal yang wajar jika seorang saksi masih dalam tahap penyidikan untuk meminta pemeriksaan ulang atas keterangan yang diberikan sebelumnya dan surat pernyataan tersebut telah dilampirkan di dalam berkas perkara dan telah menjadi satu kesatuan menjadi berkas penyidikan dan akhirnya kemudian melimpahkan berkas ke Pengadilan Negeri untuk pemeriksaan persidangan, akan tetapi surat pernyataan tersebut tidak ada ditindak lanjuti penyidik dengan melakukan pemeriksaan ulang terhadap saksi-saksi tersebut diatas, maka oleh karenanya akan hal tersebut adalah cukup beralasan jika kemudian saksi-saksi tersebut mencabut dipersidangan menyatakan dengan tegas mencabut keterangan sebelumnya di penydik kerena sejak di penyidikan saksi-saksi tersebut telah menyatakan untuk mencabut keterangannya dan meminta untuk diperiksa ulang sepanjang tentang kepemilikan narkotika Ganja tersebut, karena saksi-saksi tersebut juga dipersidangan menerangkan bahwa memang tidak mengetahui kepemilikan ganja yang ditemukan dalam perkara tersebut, sehingga apa yang dimintakan saksi tersebut beralasan dan bersesuaian dengan fakta persidangan, sedangkan suatu fakta dipersidangan sebagaimana telah diuraikan sebelumnya dalam putusan telah adanya persesuaian keterangan saksi satu dengan lainnya.

Dalam pertimbangannya Majelis Hakim berpendapat bahwa alat-alat bukti berupa keterangan saksi-saksi dan ditambah keyakinan Majelis Hakum telah mempertimbangkan dakwaan Jaksa Penuntut Umum untuk menerimanya. Pencabutan keterangan kesaksian oleh saksi sebagaimana telah diuraikan diatas, bahwa pencabutan keterangan kesaksian tidak dapat diterima oleh Majelis Hakim, terlebih perkara diatas adalah perkara narkotika. Tuduhan penyalahgunaan narkotika adalah tuduhan yang sangat serius dan saksi dalam perkara tersebut tidak boleh diperlakukan sebagaimana saksi dalam perkara perdata yang dapat mencabut kesaksiannya.

Jika peristiwa pencabutan kesaksian terus terjadi dalam perkara pidana maka hal tersebut dapat menyebabkan seolah olah pemeriksaan perkara pidana tidak dilakukan secara serius tetapi dianggap main-main saja. Disinilah diperlukan inisiatif dan kereativitas Hakim untuk menyikapi latar belakang dan sebab pencabutan kesaksian para saksi. Jika pencabutan kesaksian itu tidak jelas, maka Hakim bebas untuk menggunakan kesaksian para saksi sebagai bahan pertimbangan dan fakta hukum untuk membuat keputusan yang tepat dan adil. setelah kesaksian saksi-saksi a charge (saksi yang memberatkan) dihadapkan dengan kesaksian saksisaksi a de charge (saksi yang meringankan) karena tujuan dari putusan pengadilan adalah mencari kebenaran materii dan keadilan.

\section{D.Kesimpulan}

Berdasarkan uraian diatas maka dapat diketahui bahwa implikasi dari pencabutan keterangan BAP Saksi dalam persidangan terhadap kekuatan alat bukti adalah : Jika pencabutan BAP Saksi diterima oleh Hakim, maka konsekuensi yuridisnya adalah keterangan saksi tersebut dalam persidangan pengadilan dapat digunakan sebagai alat bukti dan keterangan saksi ditingkat penyidikan tidak dapat digunakan sama sekali untuk menemukan bukti di persidangan karena isinya dinilai tidak benar. Apabila pencabutan ditolak oleh Hakim maka konsekuensi yuridis adalah BAP saksi dalam persidangan maka konsekuensi yuridisnya adalah keterangan saksi dalam persidangan tidak dapat digunakan sebagai alat bukti, oleh 
Jurnal Magister Hukum Program Pascasarjana Universitas HKBP Nommensen

Volume or Nomor o1 Juli 2020 Halaman. 129-138 e-ISSN: 2723-164X p-ISSN: 2722-9858

http://ejournal.uhn.ac.id/index.php/opinion

karena itu ditingkat penyidiklah BAP Saksi tersebut dapat digunakan untuk menemukan bukti di persidangan. Oleh karena itu pencabutan BAP Saksi tidak ada diatur di dalam KUHAP.

\section{Daftar Pustaka}

Bambang Semedi, 2009," Modul Pemeriksaan Tersangka Dan Saksi”, Departemen Keuangan Republik Indonesia Badan Pendidikan Dan Pelatihan Keuangan Pusat Pendidikan Dan Pelatihan Bea Dan Cukai.

Martiman Prodjohamidjojo,1984, Komentar Atas KUHAP: Kitab Undang-Undang Hukum Acara Pidana, Jakarta, Pradnya Paramita

Marwan Effendi. 2005, Kejaksaan RI: Posisi Dan Fungsinya Dari Perspektif Hukum. Jakarta. Gramedia Pustaka Utama.

Peter Mahmud Marzuki, 2006, Teori dan Metodologi Penelitian Hukum Normatif, Jakarta, Prenada Media.

R Subekti,2008, Hukum Pembukitan, Cetakan Ke 17, Jakarta, Pradnya Paramita.

Simamora, Janpatar., Kepastian Hukum Pengajuan Kasasi oleh Jaksa Penuntut Umum Terhadap Vonis Bebas, Jurnal Yudisial, Komisi Yudisial RI, Vol. 7 No. 1 April 2014.

Simamora, Janpatar., Tafsir Makna Negara Hukum dalam Perspektif Undang-Undang Dasar Negara Republik Indonesia Tahun 1945, Jurnal Dinamika Hukum FH Universitas Jenderal Soedirman, Vol. 14 No. 3 September 2014.

Soedjono D, 1982, Pemeriksaan Pendahuluan, menurut KUHAP, Alumni, Bandung.

Soerjono, Soekanto dan Sri Mamudji,1995, Penelitian Hukum Normatif, Suatu Tinjauan Singkat, Jakarta, Raja Grafindo Persada.

Teguh Samudera, 2004, Hukum Acara Perdata, Bandung, Alumni.

Reza Fahlepy, Analisis Hukum Islam Terhadap Jarimah Minta-Minta Yang Dilakukan oleh Anak, Jurnal de Jure 10, No 2, 2018.

Bismar Nasution, Metode Penelitian Hukum Normatif dan Perbandingan Hukum, Makalah disampaikan pada dialog interaktif tentang Penelitian Hukum dan Hasil Penulisan Hukum pada Majalah Akreditasi, Fakultas Hukum USU, 18 Februari 2003

Hukumonline.com Kekuatan Pembuktian BAP Saksi di Persidangan, diunduh tgl 10 Mei 2020 Kitab Undang-Undang Hukum Acara Pidana, UU No 1 Tahun 1985 